\title{
Predatory and Parasitic Agents Attacking the Hippelates pusio Complex in Puerto Rico
}

\author{
E. F. Legner and E. C. Ba!l ${ }^{1,2}$
}

INTRODUC'TION

An exploratory search for natural control of Hippelates eye gnats was conducted in Puerto Rico in the spring, summer, and fall of 1963 for the purpose of introducing a greater complex of regulatory agents into eye gnat-breeding areas of southern California. The importance of these insects as vector species of human diseases has been frequently reported: Blaneo et al. (2), ${ }^{3}$ Dow and Hines (3), Kumm (4), Nulla (5), Vargas (10). They are of major concern in irrigated areas of southem California because of their role as suspected vectors of the Kochs-Weeks hacillus and as nuisance pests.

The diversified species of Hippelales reported from P'uerto Rico (Wolcott (11), Sabrosky (personal communication)) and their occurrence in relatively low numbers made this part of the world a probable site for locating a diverse parasitic fauna. Ever since Mulla's initial discovery of a cynipid parasite in 1961 (Mulla $(6,7)$ ), and subsequent finds by the authors (Bay and Legner (1)) of three additional families of parasitic Hymenoptera attacking eye gnats, it became well established that biotic agents play a role in the natural eontrol of Hippelates. By 1962 we had three parasitic species in culture at Riverside, Calif., which were discovered in southern California. With these parasites it was possible to improve techniques for securing additional species in foreign countries.

\section{MEYIIODS AND MATERIALS}

Hippelales eye gnats were captured in the field with rotten-egg and fishbait traps, and laboratory cultures were established. Eye gnat eggs secured in the rearing process were used in either of three ways: 1, The eggs were exposed overnight directly in the field using fine-mesh bolting cloth fixed to a plastic hoop; 2, eggs were seeded to artificial media for the ultimate

${ }^{1}$ Assistant Entomologists, Department of Biologieal Control, University of California, Riverside, Calif.

"We wish to thank the following who were ext remely helpful to us and made valuable suggestions in regards to the present research: Dr. Mario Pérez Escolar, Agricultural Experiment Station, Río Piedras, P.R., and Dr. J. Maldonado and 1)r. David Walker, College of Agrieulture and Mechanic Arts, University of P'uerto Rico, Mayagüez, P.R. We also thank Mr. Miguel Figueroa, graduate Research Assistant, and 'Technician Robert Medved for their aid in certain technical aspects of this study.

3 Italie numbers in parentheses refer to Literature Cited, pp. 38t-5. 
production of pupae which were then field-exposed for 2 to 4 days. Such exposure was accomplished by burying the pupae under $1 / 4$ inch of soil in small petri dishes, or by sindwiching them between two layers of 50 mesh Nitex screen fastened together with plastic hoops (fig. 1); 3, the eggs were seeded to small wax-paper-cup units containing local sandy soil and sprouted millet, or succulent weed seedlings such as Portulaca spp. (fig. 2).

Units were initially irrigated with Hyponex plant-nutrient solution, using 2 tablespoons of Hyponex per gallon of water, subsequent watering

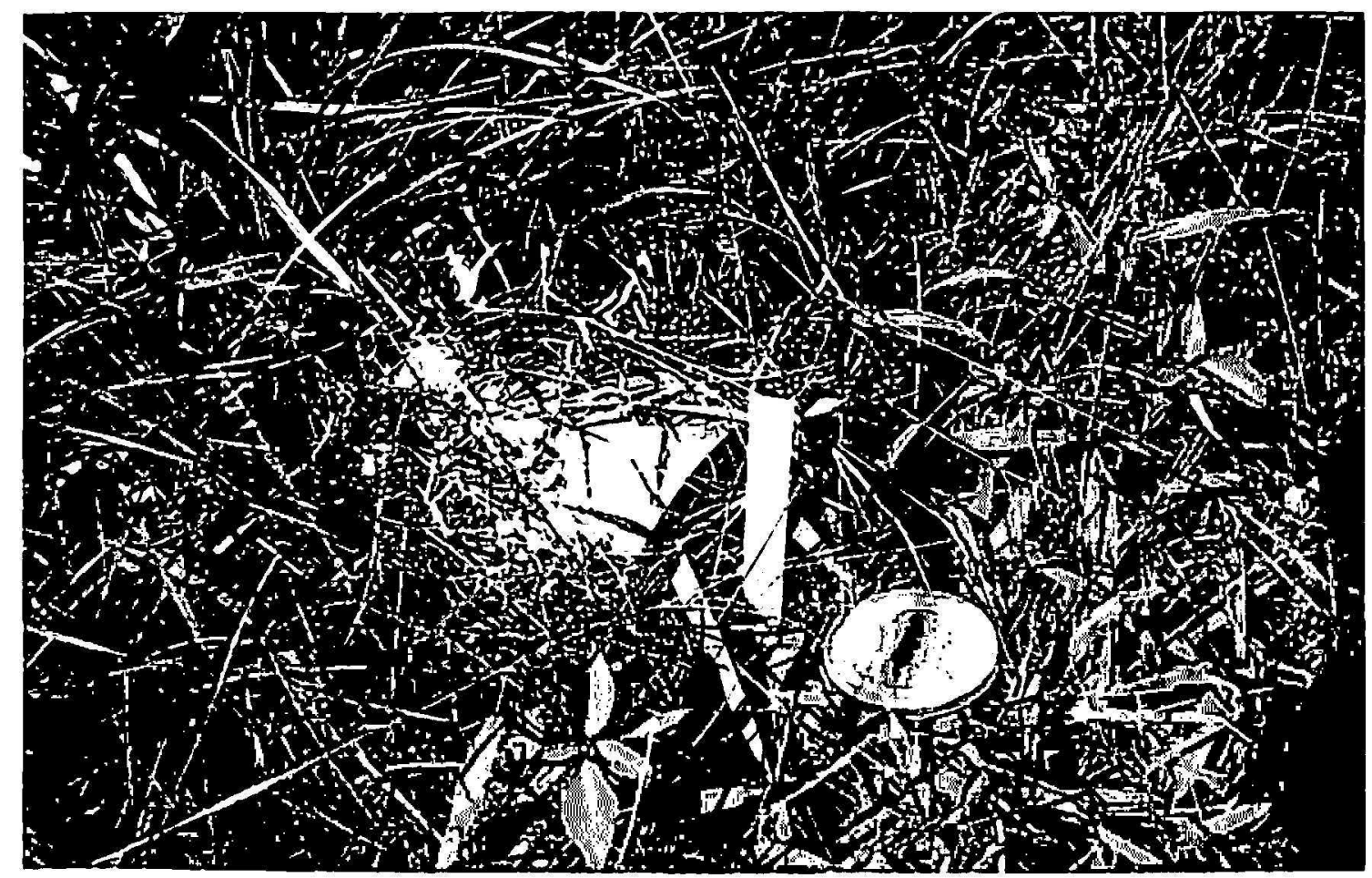

Pici. 1.-- Exposure of Hippelates pupac in a site favorable for the activity of parasites-expossure is male in a Nitex disk (right) and in a petri dish (below roof at left)

being with plain water. After 2 days when the hatched larvae had crawled to cover on the roots of the secdling plants, the units were transfered to the field where they were allowed to remain for 1 week. During this time the larvae fed and developed on the roots, and pupated, a habit which had first been noticed by the authors with California Hippelates (Bay and Legner ( $(1)$ ). Exposure was, therefore, attained of both larvae and pupac under more natural conditions. Material which had been field-exposed was returned to the laboratory and incubated for parasite and host emergence.

Host material was always exposed at or near the soil surface where natural breeding occurred (fig. 1). It was found desirable to limit such exposures to areas which were shielded from the direct rays of the sum, and thereby prevent desiccation of the living material. 
Areas monitored for parasite activity were the Lajas and Yauco valleys of the southwest, and the environs of Ponce, Caguas, Río Piedras, and Isabela.

All parasite and host material sent to California was processed in quarantine at the Department of Biological Control, University of California, at

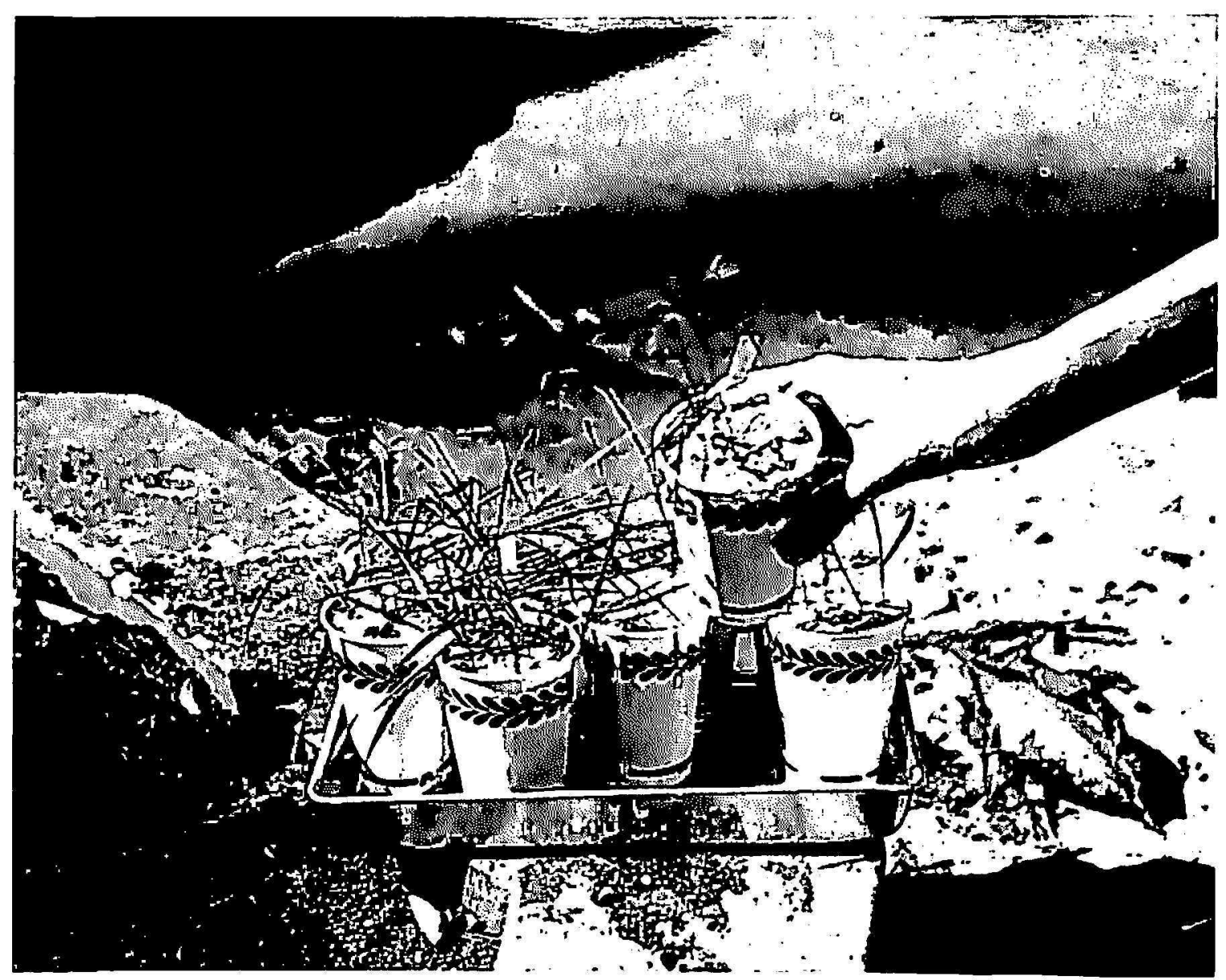

Fig. 2.-Wax-paper-cup exposure units with developing millet seedlings and larvae of Hippelales feeding on the rowts.

Riverside, where thorough checks were made to avoid the accidental introduction of a noxious organism.

\section{RESULTS AND DISCUSSION}

Over 99 percent of the Hippelates collected and reared belonged to the H. pusio complex determined by (. W. Salnrosky. Sabrosky informed us (personal communication) that the taxonomy of these insects was in revision, and that he could not classify them as distinct species. However, acrording to his original system of ('lassification (Sabrosky (9)) it was evident that about 36.3 percent of the atuptured Hippelates belonged to the 
true $H$. pusio Loew., while the remaining 63.7 percent were very likely $H$. flavipes Loew.

Results of the field exposures are listed by area in table 1 . A total of 24,492 eggs, 12,988 pupae, and 8:3 wax-paper-cup units were field-exposed during the course of the exploration. Of these, recovered material which could be held for parasite emergence totaled about 12,000 eggs, 7,998 pupae from pupal exposures, and 1,702 pupae from wax-paper-cup exposures.

No parasites emerged from exposed Hippelates eggss. Where pupae were exposed directly in the field, 6,36:3 emerged as adults, 1,614 were mummified, and 11 were parasitized; and with larval and pupal exposures in wax paper cups, of the recovered pupac, 1,592 emerged as adults, 117 were mummified, and 67 parasitized. Mummies may have resulted from parasite host feeding.

Five parasitic Hymenoptera and one Acarina species were found attacking Hippelates (table 1). The first parasite was an encyrtid, Ooencyrtus submetallicus How., determined by B. D. Burks, discovered near Jajas on April 4, 1963. One male and two female parasites cmerged from a single pupa. Only 1 out of 8 petri-dish exposure units and 1 pupa out of 20 exposed was attacked, a 5-percent parasitization. Propagation to the F-1 was accomplished in Puerto Rico with the production of a single male and female from one pupa. F-1 pupae sent to Riverside failed to emerge, and the F-1 adults reared in Puerto Rico died out after stinging and killing subjected eye gnat pupae, no development to the F-2 being therefore accomplished. O. submetallicus is a known egg-parasite of the southern green stinkbug, Nezara viridula var. smaragdula Fab. Living specimens of this parasite have recently been introduced into Hawaii for biological control (Hawaii Report (8)). Since this identification has been verified by B. D. Burks (personal communication), and is, therefore, considered to be correct, it is the first report of $O$. submetallicus attacking the pupal stage of a host. Such a combination of host-stage preference is unique in the recorded literature of the parasitic Hymenoptera.

The second parasite discovered at Lajas on April 22 was listed as an undescribed species of Spalangia by B. D. Burks, a long series of which had been previously reared from Sarcophaga sp. in 19:36. Three pupae out of 30 exposed in a Nitex disk were parasitized, a 10-percent parasitization. One Nitex disk out of three placed in the area was attacked. A single adult female parasite emerged in Riverside which gave rise to eight male progeny in the F-1 on Califomia host material.

A third organism identified with the adult stage of the eye gnat was a small undescribed species of clear mite, discovered near Aguadilla on April 26 infesting 6.1 percent of the adult population, and again on May 21 near Yauco where 6 percent of collected adults were infested. Sometimes over 
Table 1.-Field exposure of larvae and pupae of Ilippelates in Puerlo Rico during 1963

\begin{tabular}{|c|c|c|c|c|c|c|c|c|c|}
\hline \multirow{2}{*}{ Area } & \multirow{2}{*}{$\begin{array}{l}\text { Survey } \\
\text { period }\end{array}$} & \multirow{2}{*}{$\begin{array}{l}\text { Stage } \\
\text { exposerl }\end{array}$} & \multicolumn{2}{|c|}{ Exposed- } & \multirow{2}{*}{$\begin{array}{c}\text { Hosts } \\
\text { emerged }\end{array}$} & \multirow{2}{*}{$\begin{array}{c}\text { Hosts } \\
\text { parasit- } \\
\text { izedl }\end{array}$} & \multirow{2}{*}{ 窇 } & \multirow{2}{*}{$\underset{\text { Parasit- }}{\text { ization }}$} & \multirow{2}{*}{$\begin{array}{l}\text { Pred- } \\
\text { atism }\end{array}$} \\
\hline & & & Units & Hosts & & & & & \\
\hline & & & & Number & Number & Nimber & Pereent & Percent & Pcrcent \\
\hline Iajas vicinity & $\begin{array}{l}\text { Apr. 2- } \\
\text { May 31 }\end{array}$ & P'upil & $\begin{array}{l}72, \\
\text { petri }\end{array}$ & 2,798 & $7(60)$ & 3 & 83.2 & 0.3 & (i7. .4 \\
\hline Do. & $\begin{array}{c}\text { Apr. 2- } \\
\text { May 31 }\end{array}$ & do. & $\begin{array}{c}92 \\
\text { Nitex }\end{array}$ & 3,740 & 1,773 & 5 & 73.8 & .2 & 35.7 \\
\hline Do. & $\begin{array}{l}\text { Apr. 2- } \\
\text { May } 31\end{array}$ & $\begin{array}{c}\text { Larva } \\
\text { and } \\
\text { puva }\end{array}$ & $\begin{array}{l}35, \\
\text { cups }\end{array}$ & - & 249 & 0 & 88.7 & 0 & - \\
\hline Do. & $\begin{array}{l}\text { Sept. 1- } \\
13\end{array}$ & l'upa & $\begin{array}{c}\mathbf{6}, \\
\text { Nitex }\end{array}$ & 400 & 219 & 3 & 82.1 & 1.1 & 33.2 \\
\hline Do. & $\begin{array}{l}\text { Sept. 1- } \\
13\end{array}$ & $\begin{array}{l}\text { Larva } \\
\text { and } \\
\text { pupat }\end{array}$ & $\begin{array}{l}25, \\
\text { cups }\end{array}$ & - & 735 & 67 & 87.3 & 7.9 & - \\
\hline Punta Arenas & $\begin{array}{l}\text { Apr. 2- } \\
\text { Maty } 31\end{array}$ & Pupa & $\begin{array}{c}3, \\
\text { petri }\end{array}$ & 60 & 44 & 0 & 81.5 & 0 & 16.7 \\
\hline Do. & $\begin{array}{l}\text { Apr. 2- } \\
\text { May 31 }\end{array}$ & do. & $\begin{array}{l}11 \\
\text { Nitex }\end{array}$ & 220 & 121 & 0 & 70.0 & 0 & 21.4 \\
\hline Mayagïcz & $\begin{array}{l}\text { Apr. } 2 \\
\text { May } 31\end{array}$ & do. & $\begin{array}{c}10, \\
\text { pel ri }\end{array}$ & 200 & 125 & 0 & 88.7 & 0 & 29.5 \\
\hline Do. & $\begin{array}{c}\text { Apr. 2- } \\
\text { Mity } 31\end{array}$ & do. & $\begin{array}{l}22, \\
\text { Nitex }\end{array}$ & 920 & 525 & 0 & 86.9 & 0 & 34.4 \\
\hline Ponce vicinity & $\begin{array}{c}\text { Apr. 2- } \\
\text { May 31 }\end{array}$ & do. & $\begin{array}{l}14, \\
\text { petri }\end{array}$ & 490 & 223 & 0 & 81.5 & 0 & 44.1 \\
\hline Do. & $\begin{array}{c}\text { Apr. 2- } \\
\text { May 31 }\end{array}$ & do. & $\begin{array}{l}34 \\
\text { Nitex }\end{array}$ & 900 & 5.43 & 0 & 74.8 & 0 & 19.2 \\
\hline Do. & $\begin{array}{l}\text { Apr. 2- } \\
\text { May } 31\end{array}$ & $\begin{array}{l}\text { Larva } \\
\text { and } \\
\text { pupa }\end{array}$ & $\begin{array}{l}7, \\
\text { cups }\end{array}$ & - & 155 & 0 & 88.5 & 0 & - \\
\hline $\begin{array}{l}\text { Canguas } \\
\text { vicinity }\end{array}$ & $\begin{array}{c}\text { Apr. } 2 \\
\text { Maty } 31\end{array}$ & Pup:s & $\begin{array}{c}12, \\
\text { petri }\end{array}$ & +20 & 175 & 0 & 90.7 & 0 & 54.0 \\
\hline Do. & $\begin{array}{l}\text { Apr. 2- } \\
\text { May 31 }\end{array}$ & do. & $\begin{array}{l}32, \\
\text { Nitex }\end{array}$ & 860 & 625 & 0 & 81.8 & 0 & 11.0 \\
\hline Do. & $\begin{array}{l}\text { Apr. 2- } \\
\text { May } 31\end{array}$ & $\begin{array}{l}\text { Larva } \\
\text { and } \\
\text { pupa }\end{array}$ & $\begin{array}{c}8, \\
\text { cups }\end{array}$ & - & 248 & 0 & 95.3 & 0 & - \\
\hline $\begin{array}{l}\text { Río Piedras } \\
\text { vicinity }\end{array}$ & $\begin{array}{l}\text { Apr. } 2- \\
\text { M:19. } 31\end{array}$ & P'upa & $\begin{array}{c}\bar{\tau} \\
\text { petri }\end{array}$ & 350 & 114 & 0 & $\$ 2.0$ & 0 & 64.5 \\
\hline Do. & $\begin{array}{c}\text { Apr. 2- } \\
\text { May } 31\end{array}$ & do. & $\begin{array}{l}32 \\
\text { Nilex }\end{array}$ & 830 & 533 & 0 & 77.2 & 0 & 16.8 \\
\hline I)o. & $\begin{array}{l}\text { Apr. } 2- \\
\text { May } 31\end{array}$ & $\begin{array}{l}\text { Latrval } \\
\text { and } \\
\text { pupat }\end{array}$ & $\begin{array}{c}8, \\
\text { cujss }\end{array}$ & - & 205 & 0 & 94.0 & 0 & - \\
\hline $\begin{array}{l}\text { Is:abela } \\
\text { vicinity }\end{array}$ & $\begin{array}{l}\text { Apr. } 2 \\
\text { Ml:y } 31\end{array}$ & P’upa & $\begin{array}{c}8 \\
\text { Nitex }\end{array}$ & 800 & 585 & 0 & 88.6 & 0 & 9.4 \\
\hline
\end{tabular}


30 mites were found grouped around the ventral portion of the thorax on the adult gnat. Cultures of these mites with their host were sent to Riverside, but they failed to propagate. The mites were tentatively identified as the hypopial stage of soil-inhabiting Acaridiae (Suborder: Sarcoptiformes), and were probably phoretic.

A fourth Hippelates parasite discovered near Yauco on September 6 was described as a new species of Trybliographa (Didictyum) of the family Cynipidae, determined by $\mathrm{C}$. $\mathrm{H}$. Weld, attacking the larval stage of the eye gnat. Ten out of twelve and 8 out of $1: 3$ wax-paper-cup units were attacked at 2 separate sites in the area. Thirty-four out of 531 pupae, 6.4 percent, and 33 out of 321 pupae, 10.3 percent, were parasitized. This species is currently in culture at Riverside, and attempts are being made to find a suitable means for mass-rearing it.

The fifth parasite, an unidentified species of Pteromalidae, was located near Yauco on September 13 in Nitex pupal-exposure units. One of two exposed Nitex disks was attacked and 3 of 333 recovered pupae were parasitized, a 9.9-percent parasitization. Culture at Riverside was not attained.

Spalangia drosophilae Ashmead, the 6th species found in Puerto Rico, was picked up on three separate occasions. The first discovery was made on April 22 south of Lajas from pupac exposed in a petri dish. Only 1 pupa out of i30 exposed was parasitized, a 2-percent paraistization. Sul secuent recoveries were made of the adult at P'unta Arenas on April 19 and May 18. A separate culture of this strain of S. drosophilae is now being maistained at Riverside in order to compare it with a previously obtained California strain (Bay and Legner $(I)$ ).

Hippelales parasite activity based on information from the number of discoveries made, was found to be restricted to a particular kind of environment. This may be characterized as an undisturbed grassy area where sufficient moisture and adeculute shade were afforded to keep vegetation in an active growing state (fig. 3). Exposures on bare ground, either plowed or unplowed, never turned up parasites. Similarly, in woodlands where grassy spots were few, there was no observed parasite activity. Areas where rainfall was high and well distributed over the year were unfavorable. In some cases parasite activity was observed in areas with moderate rainfall when soil was sandy or drained quickly as southwest of lauco and at P'untal Arenas.

Although ants in general were voracious predators of IIippelates pupae when these were exposed, their activity could be reduced by covering the pupac with as little as 1,4 inch of soil. Ant species actually observed feeding on Hippelates pupae exposed in the field were Tapinoma melanocephahum (F.), Monomorium pharamis (L.), Wasmannia auropunctata (Reg.), Solenopsis geminala (F), and Tetramorium guincense (F.). These ants were 
undoubtedly responsible for a great deal of the predatism of exposed pupae observed in the field (table 1).

That the predators will dig down at least $1 / 4$ inch in the soil for eye gnat pupae was shown in the petri-dish exposures where percentage predatism ranged from 16.7 to 67.4 (table 1). Predators apparently did not normally mutilate hosts which were not carried away. The percentage emergence of adult gnats not parasitized or carried off by predators was not significantly different from laboratory checks $( \pm 8 \overline{5}$ percent), nor was there a significant correlation between high predator activity and a lowered viabil-

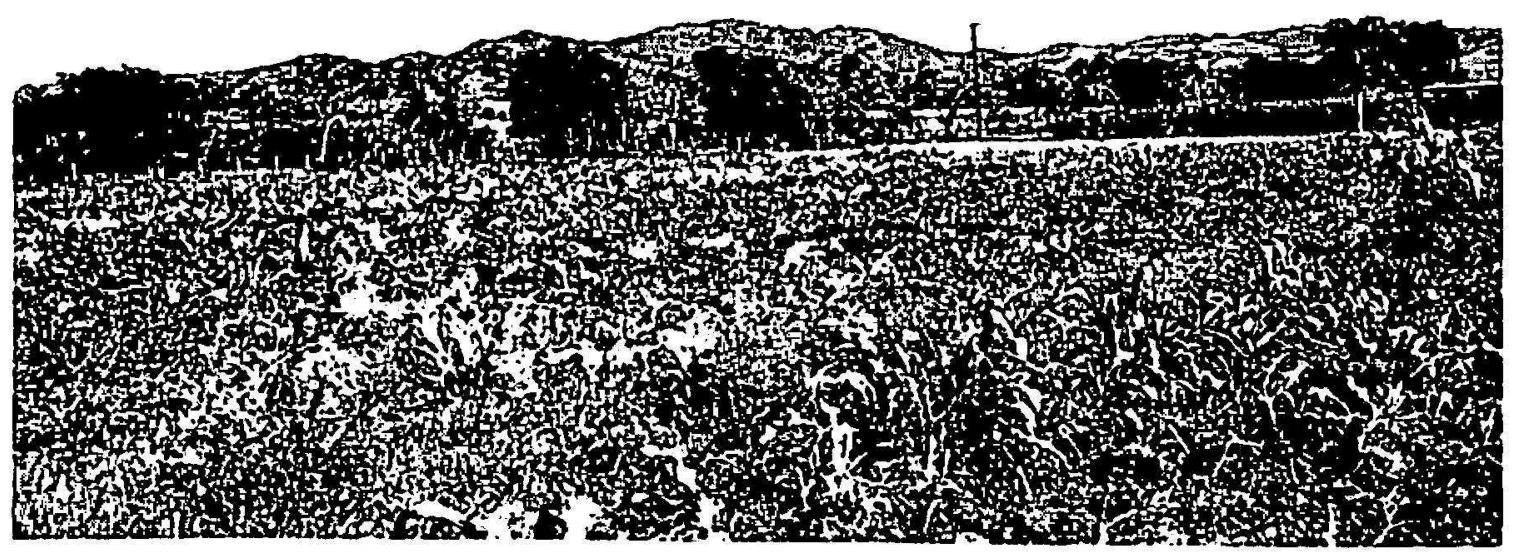

FI(i. 3.- Area near Lilas fatvorable for the breeding of Hippelates and activity of their parasites. This field has been undisturbed for several months.

ity of surviving hosts. For that matter, when pupae were exposed in Nitex disks at the soil surface and could presumably be pierced by the mandibles of attacked predators, the emergence of surviving pupae was usually unaltered. Pupae in Nitex disks were removed in separate pieces by the ants since they were too large to pass through the 50-mesh screen. Only two or three instances of mutilation were recorded, and these were probably caused by scavenger beetles or field mice which attacked Nitex units, biting holes in the sereen.

\section{CoNCLESIONS}

With due consideration of the fact that the seareh for natural enemies of Hippelates eye gnats reported herein was by no means comprehensive 
of all breeding sites, nor all factors involved in natural biotic control (e.g. pathogens), several important generalizations may be made. The attacks of hymenopterous parasites did not appear to be seasonal, as discoveries were made throughout the survey period; also the greatest parasite activity seemed to be localized in southwestern Puerto Rico, since there were no pickups, other than mites, in any other section. It would appear that pupal parasites were not as effective regulatory agents as larval parasites. The role of predators in natural control seemed to be significant, although their effectiveness on naturally breeding eye gnat populations was not measurable.

\section{SUMMARY}

Hymenopterous parasites found attacking the Hippelates pusio complex in Puerto Rico in 196:3 were Ooencyrtus submelallicus Howard (5 percent), Spalangia drosophilae Ashmead (2 percent), Spalangia nov. sp. (10 percent), Pteromalidae Genus sp. (9.9 percent), all pupal parasites; and a new species of Cynipidae, Trybliographa sp., a larval parasite (6.4 and 10.3 percent). An unidentified clear mite infested up to 6.1 percent of field-collected adults. Predacious ants were Tapinoma melanocephalum (F.), Monomorium pharaonis (L.), Wasmannia auropunclata (Reg.), Solenopsis geminala (F.), and Telramorium guineense (F.). Parasite activity was apparently not seasonal but was localized in the southwest portion of the Island.

\section{RESUMIEN}

Los parásitos himenópteros que se encontraron en Puerto Rico en 1963, atacando el complejo Hippelates pusio, eran el Ooencyrtus submetallicus Howard (5 por ciento); Spalangia drosophilae Ashmead (2 por ciento); Spalangia, n. esp. (10 por ciento); un Género sp. de la familia Pteromalidace (9.9 por ciento), todos parásitos puparios; y una nueva especie de Cynipidac, T'rybliographa sp., parásito larval (6.4 y 10.3 por ciento). Un ácaro transparente sin identificar infestó hasta el 6.1 por ciento de los adultos coleccionados en el campo. Las hormigas rapaces (que se encontraron fueron Tapinoma melanocephalum (F.), Monomorium pharaonis (L.), Wasmannia auropunclala (Reg.), Solenopsis geminala (F.), y Teliamorium guineense (F.). Ia actividad parasitaria no fue aparentemente estacional, sino que so linitó a la región suroeste de la Isla.

\section{HITERATI RL: (ITIEI)}

1. Bay, E. C., and Legner, E. F., The prospect for the biological cont rol of Hippelales collusor (Townsend) in southern California, Proc. Calif. Mosquilo C'onlrol Assoc., Inc. 81 : 7(5-9, 196i3.

2. Blanco, Y., Leon, F., and Parra, G.S. Y., Nota sobre la t ransmisión experimental 
del mal del pinto por medio de una mosea del género Hippelates, Gaz. Med. de Mexico 70 (4): $53+8,1941$.

3. Dow, R. P., and Hines, V. D), Conjunctivitis in southwest Georgia, Public Health Rpts. 72 (5): 441-8, 1957.

4. Kumm, H. W., The natural infection of Hippelales pallipes Loew. with the spirochaetes of yaws, Trans. Roy. Soc. Trop. Med. \& Hyg. 29 (3): 265-72, 1935.

5. Mulla, Mir S., Some important aspects of Hippelales gnats with a brief presentation of current research findings, Proc. \& Papers Amer. Conf. Calif. Mosquito Control Assoc. 27: 48-52, 1959.

6. -, Recovery of a eynipoid parasite from Hippelales pupae, Mosquilo News 22 (3): 301-2, 1962.

7. -, Mass rearing of three species of Hippelales eye gnats (Diptera: Chloropidae), Ann. Ent. Soc. Amer. 55 (2): 253-8, 1962.

8. Report of the Department of Agriculture of Hawaii for the period ending June 30, 1963, Insect pest control, pp. 51-7, 1963.

9. Sabrosky, C. W., The Hippelales flies or eje gnats: preliminary notes, Canad. Ent. 79: 23-27, 1941.

10. Vargas, L., Nota sobre el papel que se at ribuye a los Chloropidae en la transmisión de enfermedades, Med. 21 (391): 306-10, 1941.

11. Wolcott, G. N., The insects of Puerto Rico, J. Agr. Lniv. P.R. $\$ 2$ (4): 749-946 1948. 